\title{
Application of a modified distributed-dynamic erosion and sediment yield model in a typical watershed of a hilly and gully region, Chinese Loess Plateau
}

\author{
Lei $\mathrm{Wu}^{1,2,3}$, Xia Liu ${ }^{4}$, and Xiaoyi Ma ${ }^{1,3}$ \\ ${ }^{1}$ College of Water Resources and Architectural Engineering, Northwest A\&F University, Yangling, 712100, P.R. China \\ ${ }^{2}$ State Key Laboratory of Soil Erosion and Dryland Farming on the Loess Plateau, Northwest A\&F University, \\ Yangling, 712100, P.R. China \\ ${ }^{3}$ Key Laboratory of Agricultural Soil and Water Engineering in Arid and Semiarid Areas of Ministry of Education, \\ Northwest A\&F University, Yangling, 712100, P.R. China \\ ${ }^{4}$ Construction Department, Northwest A\&F University, Yangling, 712100, P.R. China
}

Correspondence to: Lei Wu (conquer2006@126.com)

Received: 30 August 2016 - Published in Solid Earth Discuss.: 7 September 2016

Revised: 2 November 2016 - Accepted: 7 November 2016 - Published: 28 November 2016

\begin{abstract}
Soil erosion not only results in the destruction of land resources and the decline of soil fertility, but also contributes to river channel sedimentation. In order to explore the spatiotemporal evolution of erosion and sediment yield before and after returning farmland in a typical watershed of the hilly and gully region (Chinese Loess Plateau), a distributed-dynamic model of sediment yield based on the Chinese Soil Loss Equation (CSLE) was established and modified to assess the effects of hydrological factors and human activities on erosion and sediment yield between 1995 and 2013. Results indicate that (1) the modified model has the characteristics of a simple algorithm, high accuracy, wide practicability and easy expansion, and can be applied to predict erosion and sediment yield in the study area, (2) soil erosion gradations are closely related to the spatial distribution of rainfall erosivity and land use patterns, and the current soil and water conservation measures are not efficient for high rainfall intensities, and (3) the average sediment yield rate before and after model modification in the most recent 5 years (in addition to 2013) is 4574.62 and $1696.1 \mathrm{Mg} \mathrm{km}^{-2}$, respectively, decreasing by about 35.4 and $78.2 \%$ when compared to the early governance (1995-1998). However, in July 2013 the once-in-a-century storm is the most important reason for maximum sediment yield. Results may provide an effective and scientific basis for soil and wa-
\end{abstract}

ter conservation planning and ecological construction of the hilly and gully region, Chinese Loess Plateau.

\section{Introduction}

Soil erosion is one of the main environmental risks that restrict the survival and development of human beings (Ongley et al., 2010), affect regular land development, and have been reported as the main cause of land degradation (Sun et al., 2012). According to Miao et al. (2010), soil erosion in the Chinese Loess Plateau is serious. The annual average soil loss in this region is about $1600 \mathrm{Gg}$, and the annual erosion amount of surface soil in the most seriously affected areas reaches $20 \mathrm{~mm}$ or more (Hessel and Jetten, 2007). Recent studies on the Loess Plateau are mainly focused on water erosion control in the water-wind crisscrossed erosion region, soil quality indicators in relation to land use and topography, overland flow on abandoned slopes, effects of longterm fertilizer applications on soil organic carbon and hydraulic properties, soil water content, interrill erosion on unpaved roads, and temporal variations of flow-sediment relationships (Zhao et al., 2015, 2016a; Yu et al., 2015, 2016; Shi et al., 2016; Li et al., 2016a, b; Cao et al., 2015; Gao et al., 2016), but there is little research on the distributed-dynamic simulation of erosion and sediment yield at watershed scales. 
The Majiagou River watershed belongs to the first grade tributary of the Yanhe River. It is located in the typically hilly and gully region of the Loess Plateau (Li, 2009), with a particular topography and geomorphology. It is one of the regions in the middle reaches of the Yellow River more seriously affected by soil loss (Fu et al., 2010; Jia et al., 2014). Before the implementation of China's returning farmland policy in 1997 (Zhao et al., 2016b), the soil erosion area in the Majiagou River watershed reached $72.31 \mathrm{~km}^{2}$, which accounts for $98 \%$ of the total watershed area. The soil erosion rate was up to $8740 \mathrm{Mg} \mathrm{km}^{-2} \mathrm{yr}^{-1}$; it belongs to the very intensive soil erosion region (Dang et al., 2013). After the implementation of the returning farmland to forestland project for nearly 10 years, the soil erosion rate of the Majiagou River watershed decreased to $5700 \mathrm{Mg} \mathrm{km}^{-2} \mathrm{yr}^{-1}$ in 2008 (Wu et al., 2010). Therefore, it is necessary to track spatiotemporal evolutions of erosion and sediment yield in the Majiagou River watershed, and results may provide a reference for scientific management of land resources and reasonable planning of soil and water conservation measures.

Against the international background of serious soil loss, research on monitoring, modelling, and other advanced technologies has developed rapidly in the world (Chen and Cui 2006; Cui et al., 2013; Borrelli et al., 2015). In the field of experimental study, the earliest quantitative study of soil erosion began in 1912 (Meyer, 1984); the related scholars in the world carried out long-term experimental studies in the runoff plot under rainfall and natural status (Xia et al., 1998; Zhou et al., 2000; Yu et al., 2009; Chen et al., 2010), which provides the scientific basis for the study of soil erosion and the theoretical support for the development of a factor analysis model. In the field of model study, soil erosion models may be divided into factor analysis (empirical statistical models) and physical-mechanism process models (Zhou and Shangguan, 2004; Cao et al., 2015). The factor analysis model is simple and intuitive and can be modified according to the specific application area. The typical representative is the USLE and its revised version (RUSLE) (Wischmeier and Smith, 1965, 1978; Renard et al., 1997; Xie et al., 2003; Sadeghi and Mizuyama, 2007), which have been widely used (Liu et al., 2001, 2002; Fu et al., 2001; Yin and Chen, 1989; Wang et al., 1996; Cheng et al., 2009; Arekhi et al., 2012; Ligonja and Shrestha 2015). Regarding physically based models, they may be divided into four main processes including raindrop sputtering, migration, runoff dispersing, and sediment transport (Wang et al., 2008). Meyer (1984) established the theory of shallow gully erosion and Foster et al. (1980) proposed a physically based soil erosion model. The United States Department of Agriculture (USDA) introduced the WEPP model in 1995. At the same time, in Europe and Australia, some classic physical process-based models, such as the Holland LISEM, the British EUROSEM and the Australian GUEST, were developed. Since 1980, Chinese scholars have successively established soil erosion prediction models with local characteristics (Mou and Meng, 1983;
Yang et al., 2007, 2008; Tang, 1996; Cai et al., 1996; Fan, 1985). With the development of modern information technology, the distributed and dynamic models have been developed and applied gradually (Zhao et al., 2013). In the field of distributed models, the typical soil erosion distributed models mainly include the SHE, IHDM, and EUROSEM models (Wang et al., 2003). In particular, some of the agricultural non-point source pollution evaluation models such as SWAT and AGNPS also include soil erosion evaluation modules (Zhang et al., 2007; Li et al., 2009). Dynamic models for soil erosion of small-scale watershed systems also have a wide application value (Tang and Chen, 1997; Gao and Lei, 2010; Liao et al., 2012). The most representative dynamic model is KINEROS, which simulates storm event-based sediment processes (Singh et al., 1999). In recent years, research on soil erosion has evolved rapidly with new computer-based technologies, such as GIS/RS, BP neural networks, genetic algorithms, and fruit fly algorithms (Zhao et al., 2004; Dai et al., 2008; Ochoa-Cueva et al., 2015). These can make realtime accurate simulations and assess quantitative spatiotemporal changes (Caro et al., 2012). In short, with the development and popularization of information technology, GIS/RS technology, and computing technology, research on the watershed sediment yield has become an inevitable trend, and the dynamic simulation has also become a necessary means to track temporal variations of erosion and sediment yield (Yao and Xiao, 2012).

However, the existing distributed-dynamic models which focus on event-based rainfall processes are not suitable for assessing inter-annual variability of erosion and sediment yields, and research hardly considers the effects of upstreamdownstream interactions on soil erosion and sediment yields at watershed scales. Therefore, the objectives of this study are (i) to establish and modify a yearly distributed model of watershed erosion and sediment yield and (ii) to evaluate spatiotemporal changes in erosion and sediment yield before and after returning farmland projects in the Majiagou River watershed. Results may provide a reliable scientific basis for the dynamic modelling of multi-scale erosion and sediment yield, land use planning, and watershed management.

\section{Material and methods}

\subsection{Study area}

The Majiagou River, located in western Ansai County of Yanan, northern Shaanxi Province (China), is one of the first grade tributaries of the Yanhe River (Fig. 1). It flows into the Yanhe River in Ansai County from north-west to south-east. The main channel is about $17.4 \mathrm{~km}$ in length and the average gully slope is about $6.5 \%$. The watershed $\left(73.83 \mathrm{~km}^{2}\right)$ is situated in the typical hilly and gully region of the Loess Plateau (northern China; $109^{\circ} 9^{\prime} 30^{\prime \prime}-109^{\circ} 18^{\prime} 59^{\prime \prime} \mathrm{E}$ and $36^{\circ} 49^{\prime} 42^{\prime \prime}-$ $\left.36^{\circ} 56^{\prime} 42^{\prime \prime} \mathrm{N}\right)$. The watershed belongs to a warm-temperature 


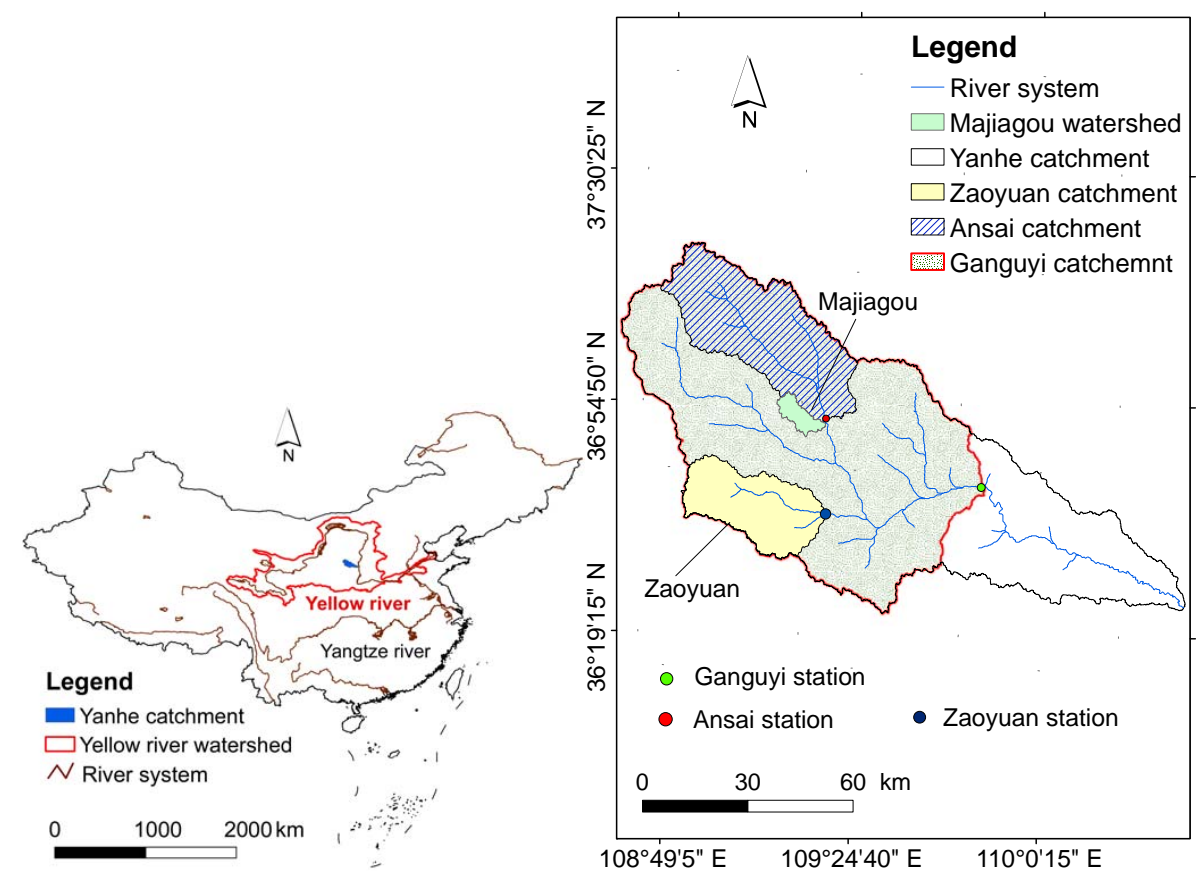

Figure 1. The relative location between the Yanhe River watershed and the Yellow River/Yellow River basin, the geographical location sketch of the Majiagou River watershed, the Zaoyuan upstream catchment, the Ansai upstream catchment, and the Ganguyi upstream catchment in the river system of the Yanhe River watershed.

and semi-arid continental monsoon climate. The evaporation capacity is above $1000 \mathrm{~mm}$; the annual average temperature is $6-11^{\circ} \mathrm{C}$. The average annual precipitation is about $500 \mathrm{~mm}$, with $80 \%$ of rainfall concentrated between May and October. Normally, precipitation occurs as intense and short storms, which favours the rapid formation of runoff, which greatly increases the risk of water erosion and flooding.

\subsection{Environmental database}

The parameters included in this study include a digital elevation model (DEM), daily precipitation data, runoff, soil properties, and land use types (Figs. 2 and 3; Table 1).

\subsection{Dynamic model of erosion and sediment yield}

Accelerated erosion risk is the result of different natural and anthropic factors (Fu et al., 2014; Tian et al., 2016). Climate, soil, topography, and vegetation are the natural factors affecting soil loss (Mu et al., 2012; Zhao et al., 2013). Inadequate land use, the destruction of forest and grass, unsuitable reclamation and overgrazing, cultivation on steep slopes, mining, road construction, and unreasonable waste soil and residue treatments are the main anthropic factors affecting soil loss (Liu et al., 2014; Lieskovský and Kenderessy 2014; Wang et al., 2016). Based on the USLE/RUSLE equations, the Chinese soil loss equation (CSLE) model (Liu et al., 2002) was selected and applied to quantitatively evaluate soil erosion of the Majiagou River watershed. The basic expression is as follows:

$Q=A \times R \times K \times L \times S \times B \times E \times T$,

where $Q$ is the annual average soil erosion rate $\left(\mathrm{Mg} \mathrm{km}^{-2} \mathrm{yr}^{-1}\right) ; A$ is the catchment area $\left(\mathrm{hm}^{2}\right) ; R$ is the rainfall erosivity factor $\left(\mathrm{MJ} \times \mathrm{mm} \mathrm{hm}^{-2} \times \mathrm{h} \times \mathrm{yr}\right) ; K$ is the soil erodibility factor $\left(\mathrm{Mg} \times \mathrm{hm}^{2} \times \mathrm{h} \mathrm{hm}^{-2} \times \mathrm{MJ} \times \mathrm{mm}\right) ; L$ is the slope length factor; $S$ is the slope gradient factor; $B$ is the biological measure factor (equivalent to factor $C$ of the RUSLE equation); $E$ is the engineering measure factor; and $T$ is the tillage measure factor.

Because not all eroded soil is actually delivered to the basin outlet, the sediment delivery ratio factor $(\lambda)$ was introduced to estimate the annual average sediment yield by Eq. (2):

$Q_{s}=A \times R \times K \times L \times S \times B \times E \times T \times \lambda$.

The dynamic-continuous modelling studies are very critical and necessary for accurately estimating annual changing trends of sediment yields (Gessesse et al., 2015). However, Eq. (2) calculates the multi-year average sediment yield amount; it is not a dynamic changing expression. According to the related study results (Long et al., 2008; Miao et al., 2012), the rainfall erosivity factor and the sediment delivery ratio factor affected by hydrological elements are defined by the dynamic hydrological factor; the biological measures, en- 
Table 1. Description and source of the environmental database in the Majiagou River watershed.

\begin{tabular}{|c|c|c|c|}
\hline Data layer & Data format & Description & Source \\
\hline DEM & Raster & $\begin{array}{l}30 \mathrm{~m} \text { spatial resolution DEM data of the } \\
\text { Majiagou watershed }\end{array}$ & $\begin{array}{l}\text { Computer Network Information Center, } \\
\text { Chinese Academy of Sciences } \\
\text { (http://datamirror.csdb.cn/index.jsp) }\end{array}$ \\
\hline Land use & Raster & $\begin{array}{l}30 \mathrm{~m} \text { spatial resolution farmland, } \\
\text { grassland, forest land, residential area, } \\
\text { water area, sand }\end{array}$ & $\begin{array}{l}\text { Data Center for Cold and Arid Region Sciences } \\
\text { (http://westdc.westgis.ac.cn/) }\end{array}$ \\
\hline Precipitation & $\mathrm{DBF}$ & $\begin{array}{l}\text { Daily values in Ansai, Yanan, Yan- } \\
\text { chang, and other rain gauges } \\
(1957-2013)\end{array}$ & $\begin{array}{l}\text { China Meteorological Data Sharing Service } \\
\text { Network (http://www.cdc.sciencedata.cn) }\end{array}$ \\
\hline Soil & $\mathrm{DBF}$ & $\begin{array}{l}\text { Physical and chemical properties (or- } \\
\text { ganic matter, soil texture, sand fraction, } \\
\text { clay fraction, structural coefficient, } \\
\text { permeability level) }\end{array}$ & $\begin{array}{l}\text { (1) Soil Survey Office in Shaanxi Province. } \\
\text { Dataset of the Second Soil Survey in Shaanxi } \\
\text { Province (1979-1990). } \\
\text { (2) Soil quality background in Loess Hilly } \\
\text { Region (2000-2008). } \\
\text { Data Sharing Infrastructure of Earth System } \\
\text { Science_Data Sharing Infrastructure of Loess } \\
\text { Plateau } \\
\text { (http://loess.geodata.cn/) }\end{array}$ \\
\hline Runoff and sediment & Excel & $\begin{array}{l}\text { Time series of annual observed values } \\
\text { in Ganguyi hydrological station } \\
\text { (1954-2012), and Ansai and Zaoyuan } \\
\text { hydrological stations (2006-2012) }\end{array}$ & $\begin{array}{l}\text { Data Sharing Infrastructure of Earth System } \\
\text { Science_Data Sharing Infrastructure of Loess } \\
\text { Plateau (http://loess.geodata.cn/) }\end{array}$ \\
\hline
\end{tabular}
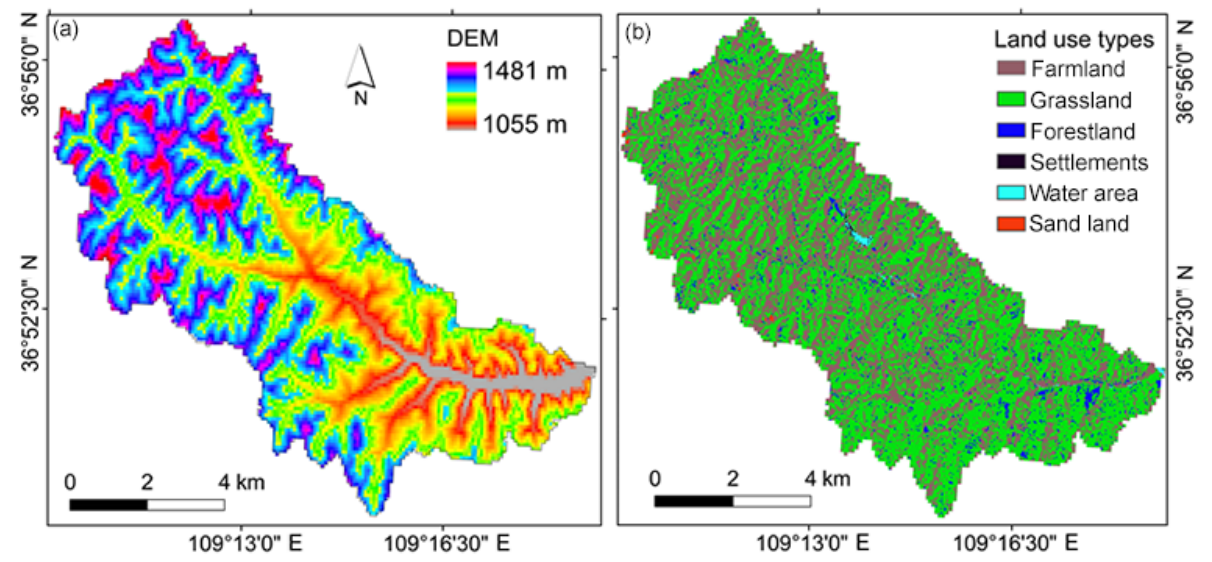

Figure 2. (a) Elevation map of the study area; (b) land use types of the Majiagon River watershed.

gineering measures, tillage measures, and the sediment delivery ratio factor affected by human activities were designed as the dynamic land management factor, so the dynamic equation of sediment yield suitable for the hilly and gully region of the Loess Plateau was put forward as follows:

$Q_{s, i}=A \times K \times L S \times\left(R_{i} \times \lambda_{q, i}\right) \times\left(B_{i} \times E_{i} \times T_{i} \times \lambda_{\mathrm{m}, i}\right)$,

where subscript $i$ represents the $i$ th year, supposing that the factor $\lambda_{i}$ can be divided approximately into the product of $\lambda_{q, i}$ related only to hydrological conditions and $\lambda_{\mathrm{m}, i}$ related only to land management measures.

Impacts of hydrological elements on sediment transport are mainly manifested in transport of sediments from erosion sources to river courses by surface runoff flow $(\mathrm{Mu}$ et al., 2012). $\lambda_{\mathrm{q}, i}$ can be estimated by the sediment transport capacity (Prosser and Rustomji, 2000). It can be supposed as follows:

$\frac{\lambda_{q, i}}{\lambda_{q}}=\frac{\mathrm{TC}_{i}}{\mathrm{TC}}=\frac{k \times q_{i}^{a} \times s^{b}}{k \times q^{a} \times s^{b}}=\left(\frac{q_{i}}{q}\right)^{1.45}$, 


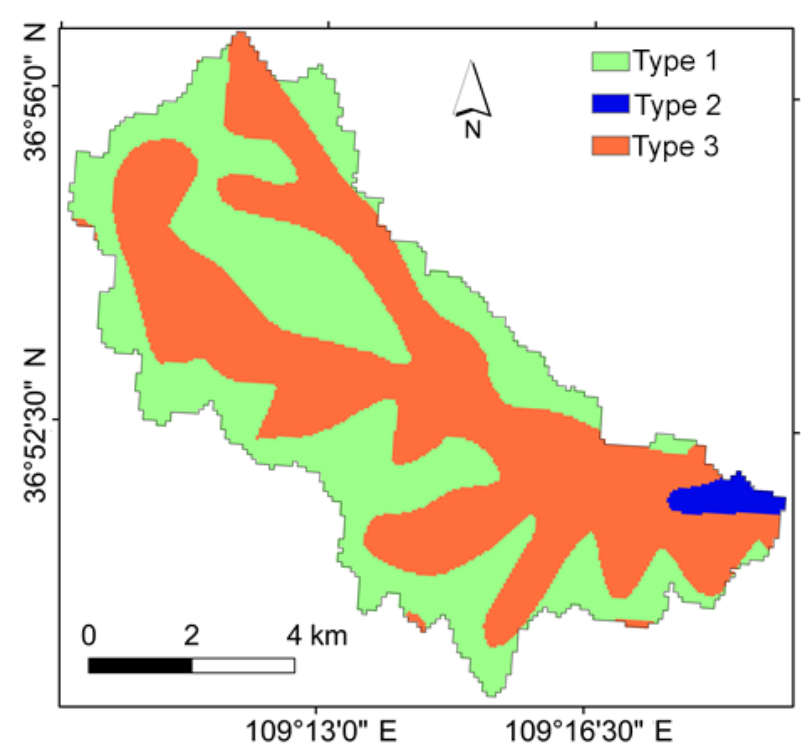

Figure 3. Soil types of the Majiagou River watershed. Type 1: tillage erosive loessal soil $(80 \%)+$ erosive loessal soil $(20 \%)$; Type 2: tillage erosive loessal soil $(80 \%)+$ calcareous alluvial soil (20\%); Type 3: erosive loessal soil $(80 \%)+$ tillage erosive loessal soil $(20 \%)$

where TC is the average sediment transport capacity per unit width of slope $\left(\mathrm{kg} \mathrm{m}^{-3}\right) ; q$ is the average runoff amount per unit width $\left(\mathrm{m}^{-3}\right) ; k, a$, and $b$ are coefficients. Those coefficients and the surface gradient factor $S$ are constants when there are no changes in underlying surfaces of runoff.

Under the annual changing conditions of $\lambda_{m, i}, B, E$, and $T$ in the study area, the dynamic land management factor was introduced and defined as

$\eta_{i}=\frac{B_{i} \times E_{i} \times T_{i} \times \lambda_{\mathrm{m}, i}}{B \times E \times T \times \lambda_{\mathrm{m}}}$.

According to Xu et al. (2012), who studied the evolution of runoff and sediment load of the Yanhe River basin between 1956 and 2009, the period between 1956 and 1969 is a sporadic governance stage with little intervention of human activities: the human intervention degree is only $0.9-3.9 \%$ and fluctuations of runoff and sediment are mainly caused by changes in natural rainfall. After this stage, human land management activities gradually became the main driving force for changes in runoff and sediment. In order to quantitatively study impacts of human land management activities on the sediment transport process, this study takes the year of 19561969 as the base period, and the years after the 1970s have been defined as the governance period (Wang et al., 2016). In agreement with Wang and Fan (2002), the fitting relationship expression $\left(R^{2}=0.912\right)$ of runoff and sediment in Ganguyi hydrological station in 1954-1969 was taken as the denominator, and the fitting relationship expression $\left(R^{2}=0.857\right)$ of runoff and sediment in 1954-1989 as the numerator. The ratio of sediment yield amount between the governance period and the base period was defined as the dynamic influencing factor which reflects effects of human land management activities on yearly changes in watershed sediment transport. The expression is

$\eta_{i}=\frac{y_{\mathrm{g}, i}}{y_{\mathrm{b}, i}}=\frac{0.449 x_{i}-5062.6}{0.4436 x_{i}-4559.9}$,

where $x_{i}$ is the runoff amount in the $i$ th year $\left(10^{4} \mathrm{~m}^{3}\right), \mathrm{n}$ is the number of years, $y_{\mathrm{g}, i}$ is the sediment amount in the $i$ th year during the governance period $\left(10^{4} \mathrm{~m}^{3}\right)$, and $y_{\mathrm{b}, i}$ is the sediment amount in the $i$ th year during the base period $\left(10^{4} \mathrm{~m}^{3}\right)$.

In summary, the dynamic model of erosion and sediment yield was determined as follows:

$Q_{s, i}=\eta_{i} \times\left(\frac{q_{i}}{q}\right)^{1.45} \times R_{i} \times \lambda \times A \times K \times L S \times B \times E \times T$,

where $\lambda$ is the average sediment delivery ratio; $B, E$, and $T$ represent the multi-year average value of each measure factor.

\subsection{Determination of model factors}

\subsubsection{The rainfall erosivity factor}

Rainfall erosivity is the potential erosive force of rainfall. Different authors have proposed simple algorithms of rainfall erosivity in different forms. In this study, a half-month simple algorithm of rainfall erosivity (Zhang et al., 2003) was applied to estimate the monthly and annual rainfall erosivity. The half-month algorithm of rainfall erosivity estimated by daily precipitation is calculated as

$R_{i}=\alpha \sum_{j=1}^{k}\left(P_{j}\right)^{\beta}$,

$\beta=0.8363+\frac{18.144}{P_{d_{12}}}+\frac{24.455}{P_{y 12}}$,

$\alpha=21.586 \beta^{-7.1891}$,

where $R_{i}$ is the rainfall erosivity value in the $i$ th half-month period $\left(\mathrm{MJ} \mathrm{mm} \mathrm{hm} \mathrm{h}^{-2} \mathrm{~h}^{-1}\right), k$ is the number of days within the half-month period, $P_{j}$ is the rainfall in the $j$ th day during the half-month period (the erosive rainfall standard $\geq 12 \mathrm{~mm}), P_{d 12}$ is the average daily rainfall when the daily rainfall $\geq 12 \mathrm{~mm}$, and $P_{y 12}$ is the average annual rainfall when the daily rainfall $\geq 12 \mathrm{~mm}$.

The annual dynamic values of the $R$ factor in the Majiagou River watershed are estimated according to the above algorithm. Results demonstrated that most of the rainfall erosivity values in the hilly and gully region of the Loess Plateau are all below $2000\left(\mathrm{MJ} \mathrm{mm} \mathrm{hm}^{-2} \mathrm{~h}^{-1}\right)$. However, Yan'an suffered a once-in-a-century storm in July 2013, which is the key reason for the abnormally large rainfall erosivity value $\left(5644.205\left(\mathrm{MJ} \mathrm{mm} \mathrm{hm}^{-2} \mathrm{~h}^{-1}\right)\right)$ of the Majiagou River watershed in 2013. In addition, spatial distributions of the average 

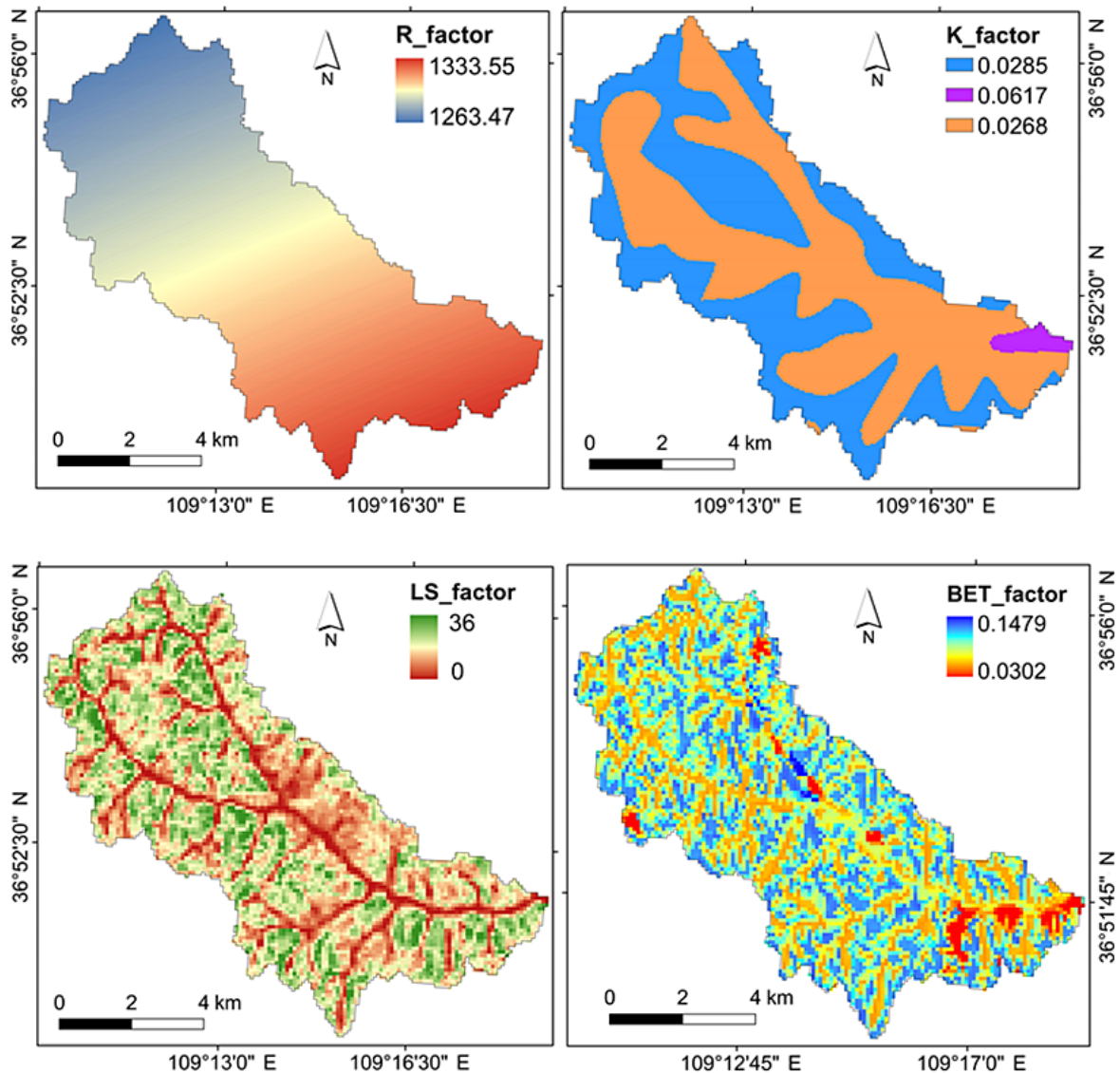

Figure 4. From left to right and up to down: spatial distribution of the annual average $R$ factor, $K$ factor, LS factor, and BET factor in the Majiagou River watershed.

annual rainfall erosivity are spatially interpolated and shown in Fig. 4.

\subsubsection{Soil erodibility factor}

According to the related studies (Zhang et al., 2007; Lu et al., 2011), the soil erodibility factor $(K)$ is calculated as

$$
\begin{aligned}
K & =0.74488 K_{n}-0.03336, \\
K_{n} & =\left[2.1 \times 10^{-4} M^{1.14}(12-\mathrm{OM})+3.25(\mathrm{SSC}-2)\right. \\
& +2.5(\mathrm{PL}-3)] / 100,
\end{aligned}
$$

where $M$ is calculated by the formula of particle mass fraction of $(0.002-0.1 \mathrm{~mm}) \times$ (particle mass fraction of $(>0.002-$ $0.05 \mathrm{~mm})+$ particle mass fraction of $(>0.05-2 \mathrm{~mm}))$; OM is the soil organic matter content, $\mathrm{g} / \mathrm{kg}$; SSC is the structural coefficient; PL is the permeability level.

Based on the soil quality survey results of the study area, the average $K$ value of soil erodibility in the watershed was calculated as $0.0542 \mathrm{Mg} \mathrm{h} \mathrm{MJ}^{-1} \mathrm{~mm}^{-1}$, which is close to results reported by Li and Zheng (2012) in the Yanhe River basin. The soil in the study area is focused on loessal soil; the $K$ values of different soil types were calculated by the above equations. Under the GIS-aided analysis conditions, different $K$ values were added to the attribute table of the soil map as a column attribute value; then, the vector map will be converted to a raster map based on the $K$ value field. Finally the spatial distribution map of the soil erodibility factor in the Majiagou River watershed was presented in Fig. 4.

\subsubsection{Topography factor}

The LS factor reflects the influencing degree of terrain factors on soil erosion; it can be divided into slope length and slope gradient factors. Many authors have suggested empirical formulas for quantitative analysis according to the standard definition of the LS factor (Fu et al., 2009; Wu et al., 2013). Through comprehensive comparison analysis, the slope length factor $(L)$ in this study was estimated by the equation below:

$$
L=\left(\frac{\lambda}{22.13}\right)^{\alpha}
$$


where $\lambda$ is the horizontal slope length; $\alpha$ is the slope length index. $\alpha$ is calculated as

$\alpha=\frac{\beta}{\beta+1}$,

where $\beta$ is calculated as

$\beta=\left(\frac{\sin \theta}{0.0896}\right) /\left[3.0(\sin \theta)^{0.8}+0.56\right]$

and $\theta$ is the slope gradient $\left({ }^{\circ}\right)$.

The slope gradient factor $(S)$ in this study was calculated using the piecewise method of gentle and steep slope gradient (McCool et al., 1987; Liu et al., 2010). Considering this mountainous terrain of the watershed, the specific expressions are as follows:

$$
\begin{array}{ll}
S=10.8 \sin \theta+0.03 & \theta<5^{\circ}, \\
S=16.8 \sin \theta-0.05 & 5^{\circ} \leq \theta \leq 10^{\circ}, \\
S=21.9 \sin \theta-0.96 & \theta>10^{\circ},
\end{array}
$$

where $\theta$ is the slope gradient $\left(^{\circ}\right)$.

In this study, the multi-year average LS value from the Majiagou River watershed is determined as 12.9 based on previous research results (Xie et al., 2009; Zhou and Li 2015). In addition, according to the above GIS-based extraction algorithm of slope gradient and slope length, the grid layers of slope gradient and slope length in the study area were extracted from the $30 \mathrm{~m}$ resolution DEM, and then the topography factor was spatially calculated by the optimal calculation formula of the slope gradient factor and the slope length factor. The spatial distribution layer of the LS factor in the study area is shown in Fig. 4.

\subsubsection{Comprehensive measure factor (BET)}

Biological measure factor ( $B$ factor) refers to the ratio of soil erosion amount between the standard cropped plot and the abandoned plot within a certain time under the same conditions (Wischmeier and Smith, 1965) and varies between 0 and 1. Engineering measure factor ( $E$ factor) is defined as the ratio of the soil erosion amount between engineering and non-engineering measures. Tillage measure factor ( $T$ factor) is the ratio of the soil erosion amount between the tilled farmland and the untilled land under the same conditions and varies between 0 and 1 (Guo et al., 2013).

Considering the synchronization of human activities on underlying surface conditions between the Majiagou River watershed and the Yanhe River basin, based on the related research results of $B, E$ and $T$ factors in the Loess hilly area (Zhang et al., 2012), 0.1562, 0.497 and 0.712 values were assigned, respectively. The spatial distributions of the average BET factor for nearly 10 years were spatially calculated (Fig. 4).

\subsubsection{The sediment delivery ratio (SDR)}

According to Jing et al. (2005), there are different fluctuations for annual SDR values of the Majiagou River water- shed, with an average value around 0.9. A SDR value of 0.92 for many years was determined as the average SDR value of the Majiagou River watershed (Zhu et al., 2007).

\section{Results and discussion}

\subsection{Validation of erosion and sediment yield}

Considering the very similar climate and underlying surface conditions, the soil erosion rate in the study area has a certain comparability with the Yanhe River watershed; the previous research results of the Yanhe River watershed can be used to verify our results. According to the dynamic simulation results of soil erosion in the Yanhe River watershed from 2001 to 2010 reported by Li and Zheng (2012), the annual average erosion rate of the Yanhe River watershed is $5812.28 \mathrm{Mg} \mathrm{km}^{-2} \mathrm{yr}^{-1}$ and has little difference with the average simulated value of $6307.86 \mathrm{Mg} \mathrm{km}^{-2} \mathrm{yr}^{-1}$ in the Majiagou River watershed from 1995 to 2012. The annual erosion rate of the Majiagou River watershed in 2008 is $2485.46 \mathrm{Mg} \mathrm{km}^{-2} \mathrm{yr}^{-1}$ and the corresponding simulated value is $2278.2 \mathrm{Mg} \mathrm{km}^{-2} \mathrm{yr}^{-1}$ with relative error $8.34 \%$. These results demonstrate that the dynamic erosion and sediment yield model has scientific rationality and good reliability. This study results can be used for adsorbed NPS pollution load estimation.

In addition, previous research results of sediment variations in Ganguyi hydrological station between 1961 and 2012 (Ren et al., 2012) and the simulation results of sediment yield in this study confirmed that sediment yield showed a decreasing trend; although there were fluctuations of different degrees in individual years (Fig. 5), it indicates that the overall changing trends of sediment yield in the study area are consistent with the background of returning farmland policy (Zhao et al., 2013); the current simulation accuracy basically meets the requirements of changing tendency evaluation. However, the original established model largely fails for the individual events, especially after 2006, when the simulated values are distinctly different from the observed values (Fig. 5). The main reason for this may be that sediment transport processes in the established model may not clearly reflect spatiotemporal variations of the watershed underlying surface, especially for the physically based complex sediment yield relations between the upper and lower areas of the watershed after returning farmland.

Therefore, it is necessary to modify the originally established model. The influencing factor considering relationships between the upper and lower reaches of the watershed was introduced to further improve the accuracy of the sediment yield model. According to the existing research results (Xie and Li, 2012), Eq. (7) can be changed into the following 


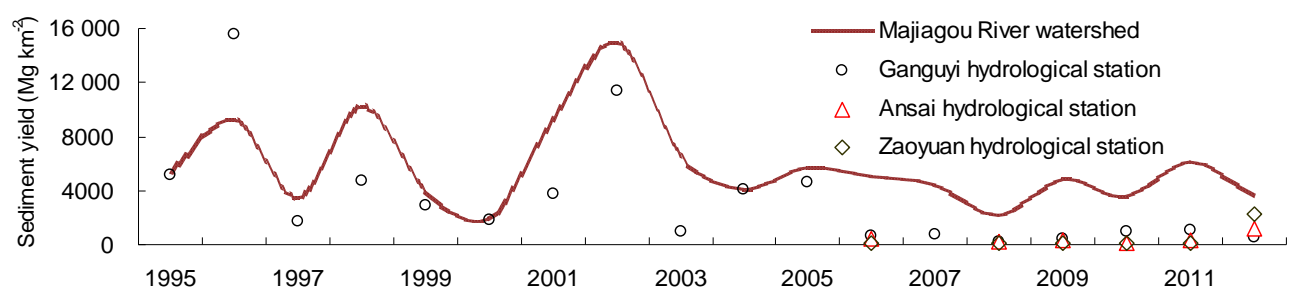

Figure 5. Validation of the sediment yield modulus among Ganguyi, Ansai, and Zaoyuan hydrological stations and the Majiagou River watershed based on the originally established model.

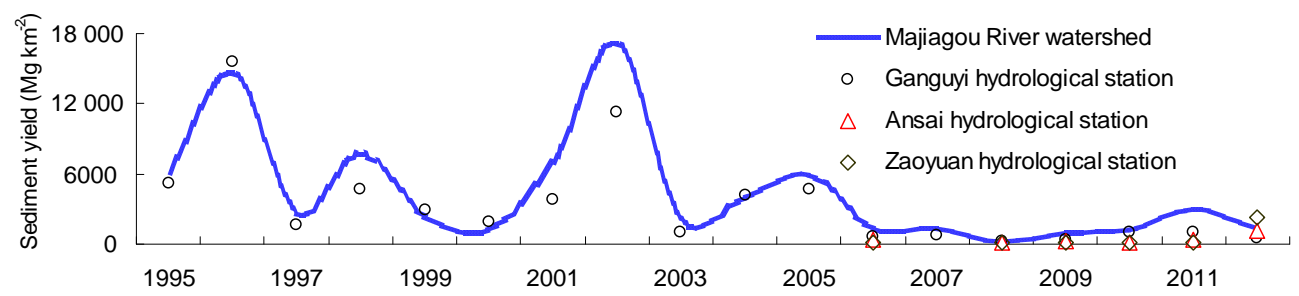

Figure 6. Validation of the sediment yield modulus among Ganguyi, Ansai, and Zaoyuan hydrological stations and the Majiagou River watershed based on the modified model.

formula:

$$
\begin{aligned}
Q_{s, i} & =\frac{Q_{\mathrm{w}, i}}{Q_{i}-Q_{\mathrm{b}, i}} \times \eta_{i} \times\left(\frac{q_{i}}{q}\right)^{1.45} \\
& \times R_{i} \times \lambda \times A \times K \times L S \times B \times E \times T,
\end{aligned}
$$

where $Q_{\mathrm{w}, i}$ is the annual saturated water when the saturated sediment transport amount is the observed sediment transport amount in a hydrological station, $Q_{\mathrm{b}, i}$ is the annual baseflow, and $Q_{i}$ is the observed annual runoff amount.

For the Ganguyi hydrological station, the simulated value of the annual average sediment yield rate after model modification from 1995 to 2012 has changed from 5803.23 to $4510.66 \mathrm{t} \mathrm{km}^{-2} \mathrm{yr}^{-1}$ between 1995 and 2012. The observed value in the Ganguyi hydrological station of the Yanhe River watershed is $3411.53 \mathrm{t} \mathrm{km}^{-2} \mathrm{yr}^{-1}$; the relative error of the modified model decreases by 30-40\% (Fig. 6). For Ansai and Zaoyuan hydrological stations, the simulation results after modification also improved a lot.

\subsection{Spatiotemporal evolutions of soil erosion gradations}

Figure 7 shows the spatial distribution of soil erosion gradations of the Majiagou River watershed in 1995 and 2010. The annual average soil erosion rate of the Majiagou River watershed is $6307.86 \mathrm{Mg} \mathrm{km}^{-2} \mathrm{yr}^{-1}$. The current situation of soil and water loss in the study area is serious and erosion control measures and adequate management plans for soil and water resources are necessary in this hilly and gully region.

Although there are no large variations in the overall spatial distribution of soil erosion between 1995 and 2010, small differences in the intensity of soil erosion rates are observed
(Table 2). The area with very low to moderately low erosion rates decreased from 55.41 to $46.93 \mathrm{Mg} \mathrm{km}^{-2} \mathrm{yr}^{-1}$ between 1995 and 2010 in the Maiagou River watershed (approximately $8.48 \%$ of the total area). In contrast, the area under moderate to extreme soil erosion rates increased from 44.59 to $53.07 \mathrm{Mg} \mathrm{km}^{-2} \mathrm{yr}^{-1}$ during the same period. The above results indicate that spatiotemporal evolutions of soil erosion intensity in the watershed are closely related to temporal and spatial distributions of rainfall intensity, rainfall duration, rainfall amount, and land use patterns. The longduration concentrated rainfall in 2010 results in a little higher erosion intensity than 1995 and easily eroded sloping farmland. It also shows that current soil and water conservation measures are not suitable for high rainfall intensity. Results potentially emphasize the necessity for further efforts in land resource management.

\subsection{Temporal evolutions of sediment yield}

Sediment transport amount in the study area has an overall decreasing trend from 1995 to 2012 (Fig. 8). The average sediment transport before and after model modification in the recent 5 years (in addition to 2013) is 4574.62 and $1696.1 \mathrm{Mg} \mathrm{km}^{-2}$, respectively. It decreased by about 35.4 and $78.2 \%$ of sediment transport from the early governance period (1995-1998). Results show that the modified model is more in accordance with practical circumstances; the main reasons for the decreasing sediment yield mainly result from water and soil conservation measures for regular rainfall events. Since the late 1990s, China has gradually carried out construction projects of farmland to forestland land use changes, beautiful mountains and rivers, warp-land dam 

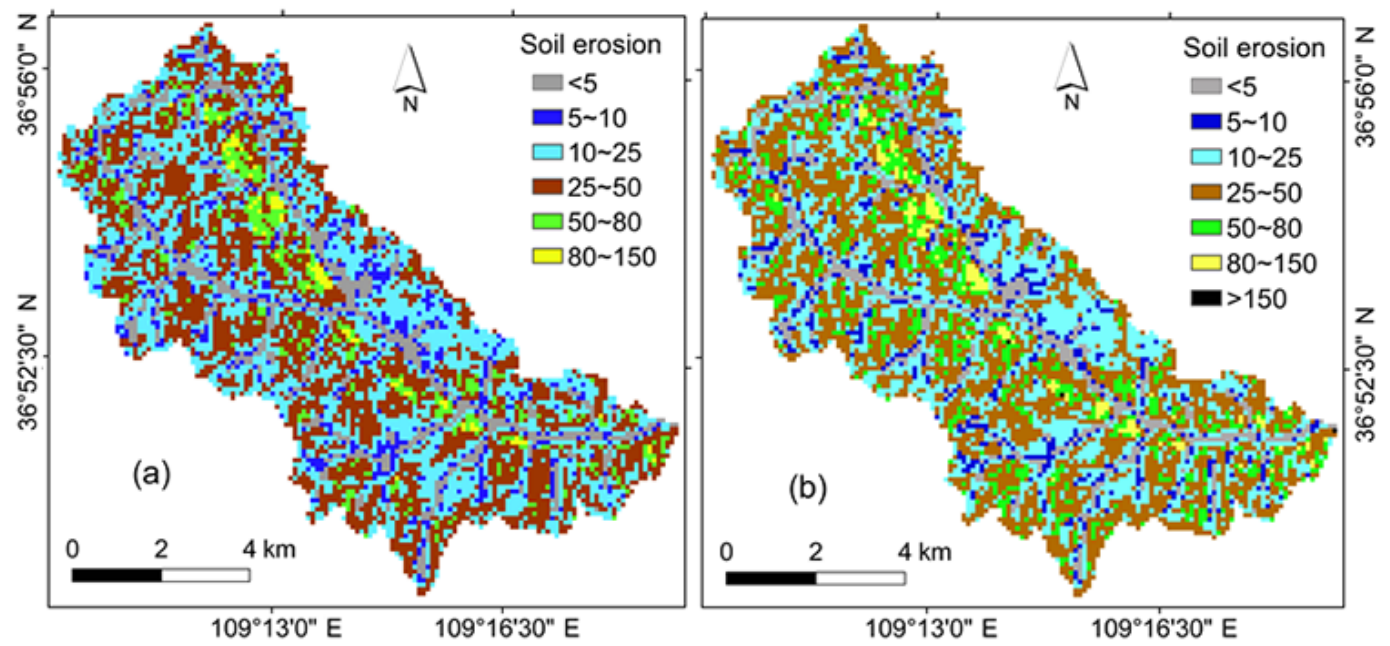

Figure 7. Spatial distribution of soil erosion gradations $\left(\mathrm{Mg} \mathrm{ha}^{-1}\right)$ of the Majiagou River watershed: (a) 1995 ; (b) 2010.

Table 2. Classification and gradation of soil erosion; percentage in the Majiagou River watershed in 1995 and 2010.

\begin{tabular}{|c|c|c|c|c|c|}
\hline \multirow{2}{*}{$\begin{array}{l}\text { Erosion } \\
\text { gradation }\end{array}$} & \multirow{2}{*}{$\begin{array}{r}\text { Erosion rate } \\
\left(\mathrm{Mg} \mathrm{km}^{-2} \mathrm{yr}^{-1}\right)\end{array}$} & \multicolumn{2}{|c|}{1995} & \multicolumn{2}{|c|}{2010} \\
\hline & & Ratio (\%) & Area $\left(\mathrm{hm}^{2}\right)$ & Ratio (\%) & Area $\left(\mathrm{hm}^{2}\right)$ \\
\hline Very low & $<5$ & 11.60 & 856.17 & 9.55 & 704.85 \\
\hline Low & $5-10$ & 8.85 & 653.08 & 8.01 & 591.36 \\
\hline Moderately low & $10-25$ & 34.96 & 2581.46 & 29.37 & 2168.31 \\
\hline Moderate & $25-50$ & 37.35 & 2757.67 & 40.63 & 2999.59 \\
\hline Intense & $50-80$ & 6.12 & 451.98 & 10.34 & 763.59 \\
\hline Very intense & $80-150$ & 1.12 & 82.63 & 2.06 & 152.32 \\
\hline Extreme & $>150$ & ND & ND & 0.04 & 2.99 \\
\hline Total & & 100 & 7383 & 100 & 7383 \\
\hline
\end{tabular}

ND: not determined

engineering, and terracing of the Yanhe River, funded by the World Bank loan in northern Shaanxi. Soil and water conservation measures implemented in the Yanhe River basin have contributed to improving underlying surface conditions and to reducing soil erosion disasters. Especially after 2003, sediment transport in the study area not only had an overall decreasing trend, but inter-annual fluctuations were also small and the whole sediment transport level was low. It also fully indicates that the effective implementation of soil and water conservation measures and the continuous improvement of underlying surface conditions have significant benefits of water and sediment reduction (Ran et al., 2006).

Soil and nutrient loss in the Loess Plateau mainly results from a few transient rainstorms (Zhang et al., 2004; Austin et al., 2004), but only serious soil erosion hazards in the study area due to the once-in-a-century storm observed in 2013 can not reflect the general sediment yield evolutions. Figure 9 shows the monthly sediment yield dynamics in 2013. It can be seen that the monthly distribution of sediment trans- port in the watershed is very uneven, and the maximum values of rainfall erosivity and sediment both occurred in July; the sediment transport capacity in July alone accounted for $96.18 \%$ of the whole annual sediment yield. The reason for this is that rainfall-induced erosion in July accounted for $80.49 \%$ of the whole yearly erosion, and it is 3.11 times more than the corresponding average value for many years. Thus a powerful hydraulic erosion force was formed due to the once-in-a-century storm. According to the statistics, the corresponding monthly runoff in the watershed also accounted for $56.22 \%$ of the total annual runoff, and it accounted for $76.79 \%$ of the multi-year average runoff amount in the Majiagou River watershed. The corresponding monthly sediment yield reached 44.5 times more than the average annual sediment yield. Therefore, the once-in-a-century storm in July 2013 is the main reason for the maximum sediment yield level and shows that a non-conventional storm plays a very critical role in the evolution process of erosion and sediment yield. 

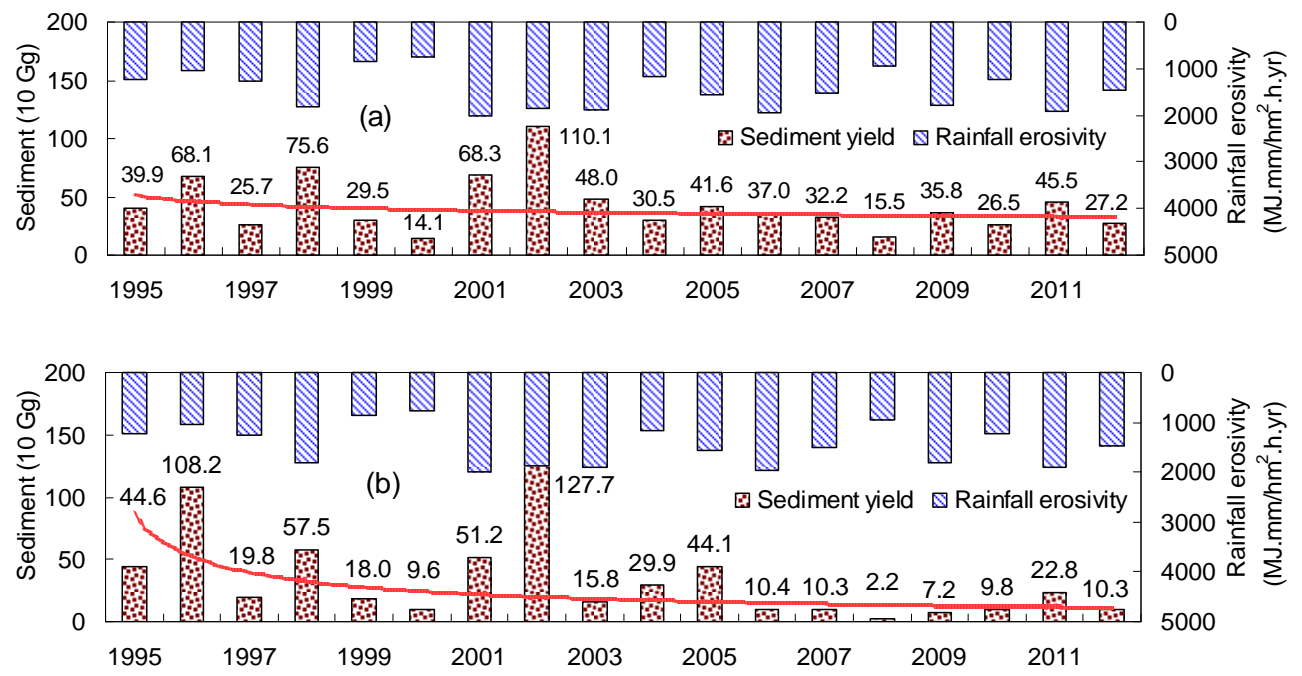

Figure 8. Comparative variations of sediment yield and rainfall erosivity in the Majiagou River watershed from 1995 to 2012: (a) the established dynamic model; (b) the modified dynamic model.

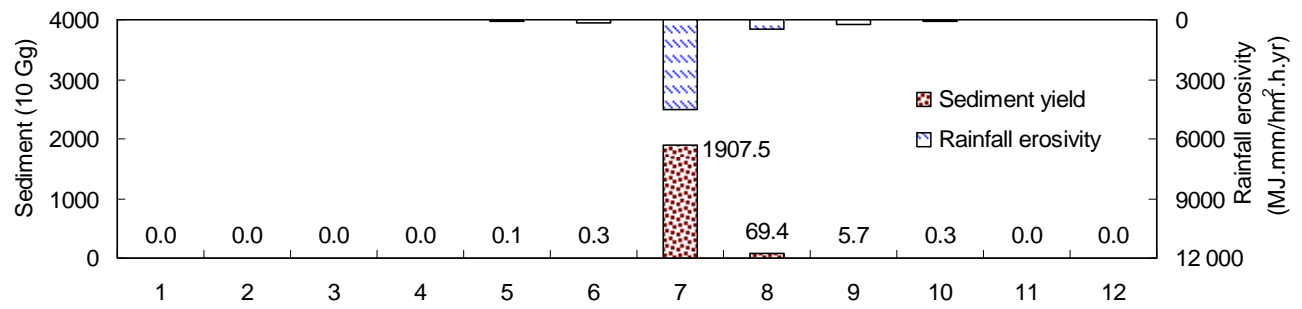

Figure 9. Comparison of monthly sediment yield and rainfall erosivity in the Majiagou River watershed in 2013.

The above analysis of sediment transport dynamics indicates that rainfall and human activity are two main factors affecting dynamic changes in soil erosion (Yao et al., 2011). Rainfall is the promotion factor for erosion evolution; it can affect the formation and development of soil erosion processes by splash effects of raindrops and erosion moving of rainfall runoff. The positive human activities are the restraining factors for erosion evolution, increasing vegetation cover, consolidating soil, weakened soil erosivity, and strengthening effects of interception.

\subsection{Spatial evolutions of sediment yield}

Due to widely distributed sloping farmland along river banks, bank erosion dominated sediment sources of the Majiagou River watershed and peak values of the sediment yield also mainly appear in these areas (Fig. 10). According to statistical analysis, the change in farmland area between 1995 and 2010 is small, while the area of forestland in 2010 increased by about $2.2 \%$ more than in 1995 . The spatial distribution map of soil erosion in these 2 years also suggests that soil erosion significantly decreased due to changes in vegetation cover and flow path, and the increase in vegetation cover (forestland) in the steep sloping land is stronger than the gen- tly sloping farmland, which results in changes in the watershed sediment distribution pattern. Through the comparative analysis, the spatial results of this study are basically consistent with the results of Zhu et al. (2016). In general, spatial and temporal variations of sediment transport in the watershed are generally related to spatial distribution of land use types; the large spatial variations of sediment transport are also closely associated with spatial changes in topography and soil (Gao et al., 2016).

\section{Conclusions}

A distributed-dynamic sediment yield model based on the CSLE equation was modified and verified to investigate impacts of returning farmland on erosion and sediment yield in the Majiagou River watershed from 1995 to 2013. Results showed that the overall status of the watershed is at intense erosion risk. Compared to the level before model modification, the multi-year average soil erosion after that decreased by about $8 \%$. Spatiotemporal evolution of soil erosion in the watershed is closely related to rainfall intensity, rainfall amount, and land use pattern. 

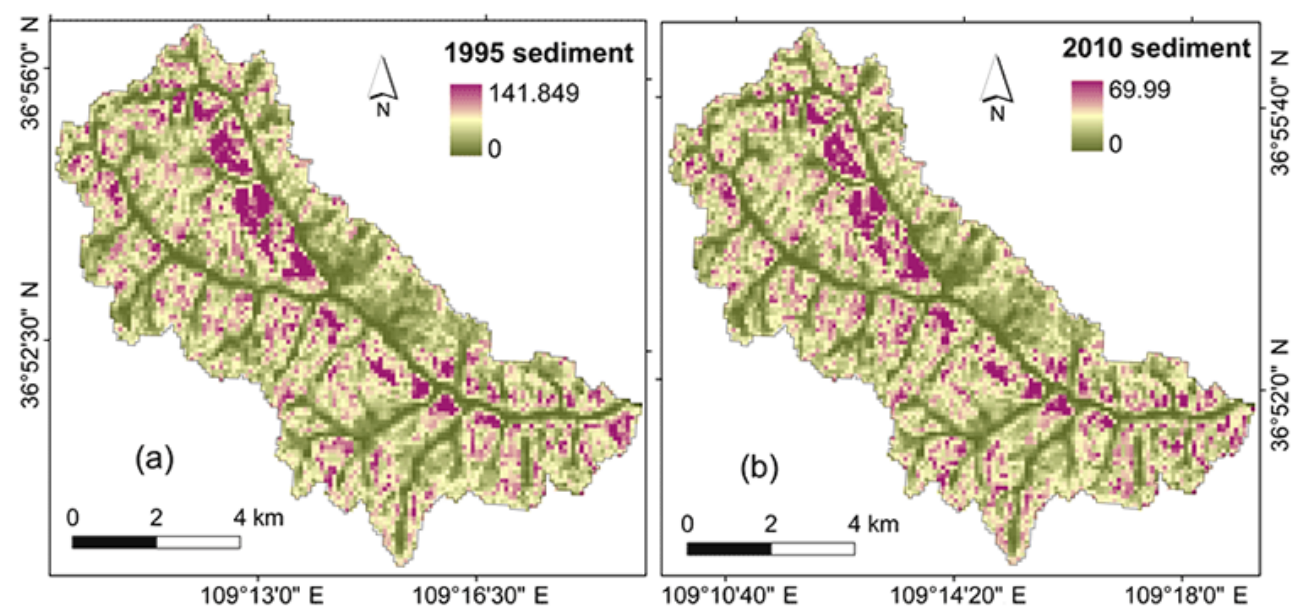

Figure 10. Spatial distribution of the sediment yield modulus $\left(\mathrm{Mg} \mathrm{ha}^{-1}\right)$ of the Majiagou River watershed: (a) 1995 ; (b) 2010.

Multi-year average sediment yield decreased from 5803.23 (before model modification) to $4510.66 \mathrm{Mg} \mathrm{km}^{-2}$ (after model modification) in the Majiagou River watershed. Annual sediment yield generally decreased between 1995 and 2012. After 2003, the annual sediment transport in the study area decreased sharply. The fluctuation trend is weak and the overall sediment yield level is relatively low, and the average sediment yield before and after model modification in the recent 5 years (in addition to 2013) is 4574.62 and $1696.1 \mathrm{Mg} \mathrm{km}^{-2}$. It has, respectively, decreased by about 35.4 and $78.2 \%$ compared with the early governance (19951998).

The implementation of large-scale soil and water conservation projects in the late 90 s of the last century has continuously improved the sediment situation of the watershed, but the changing trend of event-based rainfall urgently needs to continuously increase the level of integrated watershed management. In particular, extreme storms will lead to large fluctuations of sediment yield. For example, the once-in-acentury storm of Yan'an in July 2013 is the most important factor for the appearance of maximum sediment yield $\left(1983.36 \times 10^{4} \mathrm{Mg} \mathrm{km}^{-2}\right)$ in the watershed. Therefore, the current soil and water conservation measures are not suitable for high rainfall intensity observed in July 2013, and the results potentially emphasize the necessity for making further efforts in soil and water resource management in sloping farmland of hilly and gully regions of the Chinese Loess Plateau.

\section{Data availability}

The data sources are described in Table 1. The main data sets are from website of http://loess.geodata.cn/.
Acknowledgements. This study was supported by the National Natural Science Foundation of China (51309194, 51679206), the Fundamental Research Funds for the Central Universities (2452016120), the Special Research Foundation for Young teachers (2452015473), the open foundation of State Key Laboratory, Institute of Water and Soil Conservation, Chinese Academy of Sciences and Ministry of Water Resources (K3180099021417), the Doctoral Fund of Ministry of Education of China (20130204120034), the Initial Scientific Research Funds for PhD from Northwest A\&F University (2012BSJJ004), and the Fundamental Research Funds for the Central Universities (QN2013047).

Edited by: A. Jordán

Reviewed by: three anonymous referees

\section{References}

Arekhi, S., Shabani, A., and Rostamizad, G.: Application of the modified universal soil loss equation (MUSLE) in prediction of sediment yield (Case study: Kengir Watershed, Iran), Arab. J. Geosci., 5, 1259-1267, 2012.

Austin, A. T., Yahdjian, L., Stark, J. M., Belnap, J., Porporato, A., Norton, U., Ravetta, D. A., and Schaeffer, S. M.: Water pulses and biogeochemical cycles in arid and semiarid ecosystems, Oecologia, 141, 221-235, 2004.

Borrelli, P., Märker, M., and Schütt, B.: Modelling Post-TreeHarvesting soil erosion and sediment deposition potential in the turano river basin (Italian central Apennine), Land Degrad. Dev., 26, 356-366, 2015.

Cai, Q. G., Lu, Z. X., and Wang, G. P.: Process model of erosion and sediment yield in a typical small watershed of Loess Hilly and Gully Region, Acta Geogr. Sinica, 51, 108-117, 1996 (in Chinese with English Abstract).

Cao, L., Zhang, K., Dai, H., and Liang, Y.: Modeling interrill erosion on unpaved roads in the Loess Plateau of China, Land Degrad. Dev., 26, 825-832, 2015. 
Caro, A., Legarda, F., Romero, L., and Olondo, C.: Map on predicted deposition of Cs-137 in Spanish soils from geostatistical analyses, J. Environ. Redioactiv., 115, 53-59, 2012.

Chen, T. F. and Cui, P.: Prediction of soil erosion on the embankment slope of Xichang to Panzhihua highway, Sichuan, China, Journal of Chengdu University of Technology, Science and Technology Editon, 33, 371-375, 2006 (in Chinese with English Abstract).

Chen, Z. F., Guo, H. Z., Shi, D. M., and Tang, X. W.: Experimental study on effect of topographical factors on purple cultivated slopes land soil erosion, J. Soil Water Conserv., 24, 83-87, 2010 (in Chinese with English Abstract).

Cheng, L., Yang, Q. K., Xie, H. X., Wang, C. M., and Guo, W. L.: GIS and CSLE based quantitative assessment of soil erosion in Shaanxi, China, J. Soil Water Conserv., 23, 61-66, 2009 (in Chinese with English Abstract).

Cui, S. F., Pan, Y. H., Wu, Q. Y., Zhang, Z. H., Zhang, B. X., Hao, C. H., and Ren, S. G.: Simulation and prediction of sediment under interval coverage on Lou soil slope, J. Soil Water Conserv., 27, 7-11, 2013 (in Chinese with English Abstract).

Dai, H. L., Cao, S. L., and Geng, X. Y.: CFNN modification and its application in predicting soil erosion on slope land, Journal of Sichuan University, Engineering Science Edition, 40, 45-50, 2008.

Dang, X. H., Liu, G. B., Meng, W. W., and Jia, R. Y.: A virtual water-based analysis on the response of water resources to small watershed integrated management, Yellow River, 35, 5557, 2013 (in Chinese with English Abstract).

Fan, R. Y.: Calculation equation of soil loss in a small watershed in the middle reaches of the Yellow River, Soil Water Conserv, China, 2, 12-18, 1985 (in Chinese with English Abstract).

Foster, G. R., Overcash, M. R., and Davidson, J. M.: Soil erosion modeling: special considerations for nonpoint pollution evaluation of field-sized areas, Environmental Impact of Nonpoint Source Pollution, 213-240, 1980.

Fu, B. J., Wang, Y. F., Lu, Y. H., He, C. S., Chen, L. D., and Song, C. J.: The effects of land-use combinations on soil erosion: a case study in the Loess Plateau of China, Prog. Phys. Geog., 33, $793-$ 804, 2009.

Fu, S. H., Zhang, W. G., Liu, B. Y., Zhu, Q. J., Wu, J. D., Duan, S. H., and Li, Y. G.: Soil erosion model of small watershed in mountain area of Beijing, Res. Soil Water Conserv., 8, 114-120, 2001 (in Chinese with English Abstract).

Fu, Y. L., Zhang, X. P., Chen, F. J., Wan, L., Wu, Y., and Liu, G. B.: Land Use/Cover Pattern Survey under the Background of Grain for Green Policy Implementation in the Loess Hilly-Gully Region-A Case Study of Majiagou Catchment, Ansai County, Res. Soil Water Conserv., 17, 81-85, 2010 (in Chinese with English Abstract).

Gao, G., Ma, Y., and Fu, B.: Temporal variations of flow-sediment relationships in a highly erodible catchment of the Loess Plateau, China, Land Degrad. Dev., 27, 758-772, 2016.

Gao, P. L. and Lei, T. W.: Dynamic process simulation model for soil erosion of small-scale watershed system, Transactions of the Chinese Society of Agricultural Engineering, 26, 45-50, 2010 (in Chinese with English Abstract).

Gessesse, B., Bewket, W., and Bräuning, A.: Model-Based Characterization and Monitoring of Runoff and Soil Erosion in Re- sponse to Land Use/land Cover Changes in the Modjo Watershed, Ethiopia, Land Degrad. Dev., 26, 711-724, 2015.

Guo, Q. K., Liu, B. Y., Zhu, S. B., Wang, G. Y., Liu, Y. N., and Wang, A. J.: Soil and water conservation measures in China, Soil Water Conserv. China, 22-26, 2013 (in Chinese with English Abstract).

Hessel, R. and Jetten, V.: Suitability of transport equations in modeling soil erosion for a small Loess Plateau catchment, Engin. Geol., 91, 56-71, 2007.

Jia, L. Z., Gao, J. E., Zhang, Y. X., Zhang, M. J., Wang, X. W., and Li, X. H.: Analysis of Rainstorm Erosion Disaster in Terrace Field in Loess Hilly and Gully Region, Res. Soil Water Conserv., 21, 7-11, 2014 (in Chinese with English Abstract).

Jing, K., Wang, W. Z., and Zheng, F. L.: Soil erosion and environment in China, Science Press, Beijing, 1-359, 2005.

Li, B. B., Zheng, F. L., Long, D. C., and Jiang, Z. S.: Spatial distribution of soil erosion intensity in Zhifanggou small watershed based on GIS, Sci. Geogr. Sinica, 29, 105-110, 2009 (in Chinese with English Abstract).

Li, D. K.: Vegetation change and its response to climate in the hill and ravine region of the Loess Plateau in Northern Shaanxi, Acta Botanica Boreali-Occidentalia Sinica, 29, 867-873, 2009.

Li, H. C., Gao, X. D., Zhao, X. N., Wu, P. T., Li, L. S., Ling, Q., and Sun, W. H.: Integrating a mini catchment with mulching for soil water management in a sloping jujube orchard on the semiarid Loess Plateau of China, Solid Earth, 7, 167-175, doi:10.5194/se7-167-2016, 2016b.

Li, L., Gao, X., Wu, P., Zhao, X., Li, H., Ling, Q., and Sun, W.: Soil water content and root patterns in a rain-fed jujube plantation across stand ages on the Loess Plateau of China, Land Degrad. Dev., doi:10.1002/ldr.2540, 2016 a.

Li, T. H., and Zheng, L. N.: Soil erosion changes in the Yanhe watershed from 2001 to 2010 based on RUSLE model, Journal of Natural Resources, 27, 1164-1175, 2012 (in Chinese with English Abstract).

Liao, Y. S., Zhuo, M. N., Li, D. Q., and Cai, Q. G.: A GIS-based distributed soil erosion and sediment yield model for typical watersheds in hilly loess areas: a case study in Shejiagou catchment, Journal of Sediment Research, 7-13, 2012 (in Chinese with English Abstract).

Lieskovský, J. and Kenderessy, P.: Modelling the effect of vegetation cover and different tillage practices on soil erosion in vineyards: A case study in vráble (Slovakia) using WATEM/SEDEM, Land Degrad. Dev., 25, 288-296, 2014.

Ligonja, P. J. and Shrestha, R. P.: Soil erosion assessment in Kondoa eroded area in Tanzania using universal soil loss equation, geographic in-formation systems and socioeconomic approach, Land Degrad. Dev., 26, 367-379, 2015.

Liu, B. Y., Xie, Y., and Zhang, K. L.: Soil erosion prediction model, China Science and Technology Press, Beijing, 2001 (in Chinese).

Liu, B. Y., Zhang, K. L., and Xie, Y.: An empirical soil loss equation. In: Proceedings-Process of soil erosion and its environment effect (Vol. II), 12th international soil conservation organization conference, 21-25, 2002.

Liu, B. Y., Bi, X. G., and Fu, S. H.: Beijing Soil Erosion Equation, Science Press, Beijing, 52-67, 2010 (in Chinese).

Liu, X. Y., Yang, S. T., Dang, S. Z., Luo, Y., Li, X. Y., and Zhou, $X$.: Response of sediment yield to vegetation restoration at a large spatial scale in the Loess Plateau, Science China Techno- 
logical Sciences, 57, 1482-1489, 2014 (in Chinese with English Abstract).

Long, T. Y., Li, J. C., and Liu, L. M.: Adsorbed nonpoint source pollution load of Jialing River basin, Environ. Sci., 29, 18111817, 2008 (in Chinese with English Abstract).

Lu, J. Z., Chen, X. L., Li, H., Liu, H., Xiao, J. J., and Yin, J. M.: Soil erosion changes based on GIS/RS and USLE in Poyang lake basin, Transactions of the CSAE, 27, 337-344, 2011.

McCool, D., Brown, L. C., Foster, G. R., Mutchler, C. K., and Meyer, L. D.: Revised slope steepness factor for the Universal Soil Loss Equation, Transaction of the ASAE, 30, 1387-1396, 1987.

Meyer, L. D.: Evolution of the universal soil loss equation, J. Soil Water Conserv., 39, 99-104, 1984.

Miao, C. Y., Ni, J. R., and Borthwick, A. G. L.: Recent changes of water discharge and sediment load in the Yellow River basin, China, Prog. Phys. Geog., 34, 541-561, 2010.

Miao, C. Y., Yang, L., Chen, X. H., and Gao, Y.: The vegetation cover dynamics (1982-2006) in different erosion regions of the Yellow River basin, China. Land Degrad. Dev., 23, 62-71, 2012.

Mou, J. Z. and Meng, Q. M.: Calculation of sediment transport capacity in small and medium river basins in northern part of Shaanxi Province, Yellow River, 35-37, 1983 (in Chinese with English Abstract).

Mu, X. M., Zhang, X. Q., Shao, H. B., Gao, P., Wang, F., Jiao, J. Y., and Zhu, J. L.: Dynamic changes of sediment discharge and the influencing factors in the Yellow River, China, for the recent 90 years, CLEAN-Soil, Air, Water, 40, 303-309, 2012.

Ochoa-Cueva, P., Fries, A., Montesinos, P., Rodríguez-Díaz, J. A., and Boll, J.: Spatial Estimation of soil erosion risk by land-cover change in the Andes of Southern Ecuador, Land Degrad. Dev., 26, 565-573, 2015.

Ongley, E. D., Zhang, X., and Yu, T.: Current status of agricultural and rural nonpoint source pollution assessment in China, Environmental Pollution, 158, 1159-1168, 2010.

Prosser, I. P. and Rustomji, P.: Sediment transport capacity relations for overland flow, Prog. Phys. Geog., 24, 179-193, 2000.

Ran, D. C., Liu, B., Wang, H., Luo, Q. H., and Ma, Y.: Effect of soil and water conservation measures on flood and sediment reduction in typical tributaries of the middle reaches of the Yellow River, The Yellow River Water Conservancy Press, Zhengzhou, 2006 (in Chinese with English Abstract).

Ren, Z. P., Zhang, G. H., and Yang, Q. K.: Characteristics of runoff and sediment variation in Yanhe River basin in last 50 years, J. China Hydro., 32, 81-86, 2012 (in Chinese with English Abstract).

Renard, K. G., Foster, G. R., Weesies, G. A., McCool, D. K., and Yoder, D. C.: Predicting soil erosion by water: A guide to conservation planning with the Revised Universal Soil Loss Equation (RUSLE), USDA, Agriculture Handbook No. 703. US Department of Agriculture, Washington, DC, 367-384, 1997.

Sadeghi, S. H. R. and Mizuyama, T.: Applicability of the Modified Universal Soil Loss Equation for prediction of sediment yield in Khanmirza watershed, Iran, Hydrol. Sci. J., 52, 1068-1075, 2007.

Shi, Y., Zhao, X., Gao, X., Zhang, S., and Wu, P.: The effects of long-term fertilizer applications on soil organic carbon and hydraulic properties of a loess soil in China, Land Degrad. Dev., 27, 60-67, 2016.
Singh, R., Panigrahy, N., and Philip, G.: Modified rainfall simulator infiltrometer for infiltration, runoff and erosion studies, Agr. Water Manage., 41, 167-175, 1999.

Sun, B., Zhang, L. X., Yang, L. Z., Zhang, F. S., Norse, D., and Zhu, Z. L.: Agricultural Non-Point Source Pollution in China: Causes and Mitigation Measures, AMBIO, 41, 370-379, 2012.

Tang, L. Q.: Sediment yield model of River Basin, Adv. Water Sci., 7, 43-51, 1996.

Tang, L. Q. and Chen, G. X.: A dynamic model of runoff and sediment yield from small watershed, J. Hydrodynam., 12, 164-174, 1997.

Tian, P., Zhai, J., Zhao, G., and Mu, X.: Dynamics of Runoff and Suspended Sediment Transport in a Highly Erodible Catchment on the Chinese Loess Plateau, Land Degrad. Dev., 27, 839-850, 2016.

Wang, G. and Fan, Z.: Study on the changes of water and sediment in the Yellow River - Analysis on the variation of water and sediment of the Yanhe River, Zhengzhou, The Yellow River Water Conservancy Press, 1, 623-643, 2002.

Wang, H., Cai, Q. G., and Zhu, Y. D.: Evaluation of the EUROSEM model for predicting water erosion on steep slopeland in the Three Gorges Reservoir Area, China, Geogr. Res., 22, 579-589, 2003.

Wang, S., Fu, B. J., Piao, S. L., Lü, Y. H., Ciais, P., Feng, X. M., and Wang, Y. F.: Reduced sediment transport in the Yellow River due to anthropogenic changes, Nat. Geosci., 9, 38-41, 2016.

Wang, S. W., Li, J. Y., Xu, Z. X., and Zhang, N.: Soil erosion model studies: A state - of-the art review, Beijing, Sciencepaper Online, http://www.paper.edu.cn/releasepaper/content/200803-986 (last access: 6 July 2016), 2008 (in Chinese with English Abstract).

Wang, Z. S., Wang, Z. Q., and Liu, Z.: Quantitative study on spatial variation of soil erosion in a small watershed in the Loess hilly region, J. Soil Eros. Soil Conserv., 2, 1-10, 1996 (in Chinese with English Abstract).

Wischmeier, W. H. and Smith, D. D.: Predicting rainfall-erosion losses from cropland east of the Rocky Mountains: Guide for selection of practices for soil and water conservation, USDA Agricultural Handbook, Washington DC, 1965.

Wischmeier, W. H. and Smith, D. D.: Predicting Rainfall Erosion losses, A Guide to Conservation Planning with the Universal Soil loss Equation, Agriculture Handbook No. 537, United States Department of Agriculture, Washington DC, 1978.

Wu, L., Long, T. Y., Liu, X., and Ma, X. Y.: Modeling impacts of sediment delivery ratio and land management on adsorbed non-point source nitrogen and phosphorus load in a mountainous basin of the Three Gorges reservoir area, China, Environ. Earth Sci., 70, 1405-1422, 2013.

Wu, Y., Zhang, X. P., Chen, F. J., Wan, L., Fu, Y. L., and Liu, G. B.: Preliminary investigation on soil erosion and spatial distribution after returning farmland in typical watershed of Northern Shaanxi Province, Res. Soil Water Conserv., 17, 29-33, 2010 (in Chinese with English Abstract).

Xia, C. L., Shi, Z. G., Yang, Y. S., and Ou, Y. F.: Experimental study of hillside topographic factor of soil erosion in Anhui province, Journal of Hefei University of Technology, 21, 7-11, 1998 (in Chinese with English Abstract).

Xie, H. X., Li, R., Yang, Q. K., Li, J., and Liang W.: Effect of Returning Farmland to Forest (Pasture) and Changes of Precipita- 
tion on Soil Erosion in the Yanhe Basin, Sci. Agr. Sinica, 42, 569-576, 2009 (in Chinese with English Abstract).

Xie, W. C. and Li, T. H.: Research Comment on Watershed Sediment Delivery Ratio, Acta Scientiarum Naturalium Universitatis Pekinensis, 48, 685-694, 2012 (in Chinese with English Abstract).

Xie, Y., Lin, Y., and Zhang, Y.: The development and application of the Universal Soil Loess Equation, Prog. Geogr., 22, 279-287, 2003 (in Chinese with English Abstract).

Xu, X. X., Gao, Z. X., and Zhao, J. N.: Trends of runoff and sediment load of Yanhe River basin and their related driving forces during 1956-2009, J. Sedim. Res., 12-18, 2012 (in Chinese with English Abstract).

Yang, T., Chen, J. R., Yao, W. Y., Shi, X. J., Huang, G. R., and Xie, H. H.: Application of DEM-based runoff and sediment yield modeling in the hilly loess region_case study on two typical small catchments in the middle stream of Yellow River, J. Hydrodyn. A, 22, 583-591, 2007 (in Chinese with English Abstract).

Yang, T., Chen, J. R., Zhou, Y., Yao, W. Y., Chen, X., Shi, X. J., $\mathrm{Xu}$, Y., and Huang, G. R.: Scenario simulation of runoff and sediment processes in the small catchment in the hilly-gully region of Loess Plateau, Science of Soil and Erosion Conservation, 6, 8-14, 2008 (in Chinese with English Abstract).

Yao, W. Y. and Xiao, P. Q.: Research direction of the study of soil erosion in the Loess Plateau, Adv. Sci. Technol. Water Res., 32, 73-78, 2012 (in Chinese with English Abstract).

Yao, W. Y., Xu, J. H., and Ran, D. C.: Analysis and evaluation of water and sediment variation in the Yellow River basin, The Yellow River Water Conservancy Press, Zhengzhou, 2011 (in Chinese).

Yin, G. K. and Chen, Q. L.: Characteristic index and statistical model of sediment yield in small drainage basins of Loess Plateau in China, Acta Geogr. Sinica, 44, 32-44, 1989 (in Chinese with English Abstract).

Yu, G. Q., Li, Z. B., Zhang, X., Li, P., Chen, L., and Jia, L. L.: Experimental study on runoff erosion and sediment yield under field simulated rainfall conditions, J. Soil Water Conserv., 23, 10-14, 2009 (in Chinese with English Abstract).

Yu, W. J., Jiao J. Y., Chen, Y., Wang D. L., Wang, N., and Zhao, H. K.: Seed removal due to overland flow on abandoned slopes in the Chinese Hilly Gullied Loess Plateau Region, Land Degrad. Dev., doi:10.1002/ldr.2519, 2016.

Yu, Y., Wei, W., Chen, L. D., Jia, F. Y., Yang, L., Zhang, H. D., and Feng, T. J.: Responses of vertical soil moisture to rainfall pulses and land uses in a typical loess hilly area, China, Solid Earth, 6, 595-608, doi:10.5194/se-6-595-2015, 2015.

Zhang, K. L., Peng, W. Y., and Yang, H. L.: Soil erodibility and its estimation for agricultural soil in China, Acta Pedologica Sinica, 44, 7-13, 2007 (in Chinese with English Abstract).

Zhang, Q. L., Chen, Y. X., Yu, Q. G., Deng, H., and Tian, P.: A review on nonpoint source pollution models, Chinese J. Appl. Ecol., 18, 1886-1890, 2007 (in Chinese with English Abstract).
Zhang, S. G., Zhang, X. H., and Wang, Y. L.: Reflections on non point source pollution control problem in the Yellow River, Soil Water Conserv. China, 11-12, 2004 (in Chinese with English Abstract).

Zhang, W. B., Xie, Y., and Liu, B. Y.: Spatial variation of rainfall erosion in China, J. Mt. Sci., 21, 33-40, 2003.

Zhang, Y., Liu, X. C., Li, Z. G., and Zhu, Q. K.: Surveying soil erosion condition in Loess Plateau using soil erosion model, Transactions of the Chinese Society of Agricultural Engineering, 28, 165-171, 2012 (in Chinese with English Abstract)

Zhao, C., Gao, J., Huang, Y., Wang, G., and Xu, Z.: The contribution of Astragalus adsurgens roots and canopy to water erosion control in the water-wind crisscrossed erosion region of the Loess Plateau, China, Land Degrad. Dev., doi:10.1002/ldr.2508, 2016a.

Zhao, G., Mu, X., Wen, Z., Wang, F., and Gao, P.: Soil erosion, conservation, and eco-environment changes in the Loess Plateau of China, Land Degrad. Dev., 24, 499-510, 2013.

Zhao, G., Mu, X., Jiao, J., An, Z., Klik, A., Wang, F., Jiao, F., Yue, X., Gao, P., and Sun, W.: Evidence and causes of spatiotemporal changes in runoff and sediment yield on the Chinese Loess Plateau, Land Degrad. Dev., doi:10.1002/ldr.2534, 2016b.

Zhao, X., Wu, P., Chen, X., Helmers, M. J., and Zhou, X.: Runoff and sediment yield under simulated rainfall on hillslopes in the loess plateau of china, Soil Res., 51, 50-58, 2013.

Zhao, X., Wu, P., Gao, X., and Persaud, N.: Soil quality indicators in relation to land use and topography in a small catchment on the Loess Plateau of China, Land Degrad. Dev., 26, 54-61, 2015.

Zhao, X. N., Wu, P. T., Feng, H., Wang, W. Z., and Wu, F. Q.: Research on slope soil erosion based on manpower neural network, Sci. Soil Water Conserv., 2, 32-35, 2004 (in Chinese with English Abstract).

Zhou, P. H., Zhang, X. D., and Tang, K. L.: Rainfall installation of simulated soil erosion experiment hall of the State Key Laboratory of Soil Erosion and Dryland Farming on Loess Plateau, Bull. Soil Water Conserv., 20, 27-30, 2000 (in Chinese with English Abstract).

Zhou, Z. C. and Shangguan, Z. P.: Overview on soil erosion model research, Sci. Soil Water Conserv., 2, 52-55, 2004 (in Chinese with English Abstract).

Zhou, Z. X. and Li, J.: The correlation analysis on the landscape pattern index and hydrological processes in the Yanhe watershed, China, J. Hydrol., 524, 417-426, 2015.

Zhu, H. F., Kang, M. Y., Zhao, W. W., and Guo, W. W.: Effects of soil and water conservation measures on erosion, sediment delivery and deposition in Yanhe River basin, Res. Soil Water Conserv., 14, 1-4, 2007 (in Chinese with English Abstract).

Zhu, Q. K., Qin, W., and Zhang, Y.: Soil erosion and sediment yield and its response to vegetation restoration in the watershed, Science Press, Beijing, 2016 (in Chinese). 